dr inż. Marek Sobaś

Instytut Pojazdów Szynowych ,TABOR”

\title{
Analiza usprężynowania wózków wagonów towarowych typu Y25
}

\begin{abstract}
$W$ artykule przedstawiono dalsza problematykę sprężyn śrubowych zawieszenia pierwszego stopnia wózków wagonów towarowych typu Y25 w świetle obliczeń wytrzymałościowych, technologii wykonania, właściwego doboru materiału na wykonanie sprężyn zawieszenia pierwszego stopnia oraz niektórych doświadczeń eksploatacyjnych. Obliczenia wytrzymalościowe przeprowadzono dla obciqżeń pionowych i poprzecznych działajacych na sprężynę zewnętrznq $i$ wewnętrznq.
\end{abstract}

\section{WSTĘP}

Wózki wagonów towarowych z zawieszeniem typu Y25, wymienione w karcie UIC 500 [3] podlegają bardzo wysokiemu reżimowi wytrzymałościowemu. Obliczenia, które zostały przedstawione w [1], były ograniczone jedynie do ruchu pionowego. Karta UIC 500 jest rezultatem prac standaryzacyjnych, przedstawionych w raporcie ORE/ERRI B12 Rp.14 [12]. W rzeczywistości konstrukcja wózków z zawieszeniem Y25 (Y25L, Y25XL) posiadają luz poprzeczny pomiędzy korpusami prowadnicy oraz korpusem maźnicy wynoszący $\pm 10 \mathrm{~mm}$. Z związku z tym komplet sprężyn (sprężyna zewnętrzna + sprężyna wewnętrzna) jest dodatkowo wytężony od obciążeń poprzecznych. W celu wyznaczenia naprężeń od sił poprzecznych należy najpierw określić sztywność poprzeczną obydwu sprężyn. Naprężenia od sił poprzecznych dodaje się algebraicznie do naprężeń, wynikających z sił pionowych. Naprężenia w kierunku poprzecznym są dodatkowym czynnikiem, który uzasadnia użycie materiałów stopowych o wysokiej wytrzymałości zmęczeniowej oraz statycznej. Kolejnym czynnikiem, który poważnie wzmacnia wytrzymałość zmęczeniową jest prawidłowa technologia wykonania, która jest przedstawiona w karcie UIC 822 [7]. Jak pokazuje praktyka eksploatacyjna europejskich zarządów kolejowych, wózki wagonów towarowych z zawieszeniem typu Y25 cechują się dużą niezawodnością, natomiast produkcja sprężyn dla tych wózków jest opanowana przez krajowe oraz zagraniczne wytwórnie sprężyn. Obliczenia sztywności poprzecznych sprężyn oraz naprężenia tnące od tych sił przedstawiono dla rodziny wózków Y25L, przeznaczonych dla wagonów towarowych o nośności odpowiadającej naciskowi zestawu kołowego 22,5 t na tor. Zgodnie $\mathrm{z}$ tendencjami rozwojowymi usprężynowanie wózków typu Y25Cs jest stopniowo zastępowane sprężynami wózków typu Y25L z uwagi na uproszczenie produkcji oraz uniknięcia pomyłek podczas remontów. $Z$ porównania parametrów geometrycznych zawartych w tabelach $1 \mathrm{i}$ 2, zamieszczonych w [1] wynika, że różnice geometryczne są niewielkie i wynikają tylko i wyłącznie z zamiaru dostosowania sprężyn do reżimu obciążeniowego, wynikającego na nacisku zestawu kołowego na tor, wynoszącego $20 \mathrm{t}$ oraz 22,5 t. Wpływ tego zabiegu na bezpieczeństwo przed wykolejeniem podczas przejazdu wagonu wózkowego przez tory wichrowate jest osobnym zagadnieniem, gdyż sprężyny śrubowe wózków Y25L są sztywniejsze od sprężyn wózków rodziny Y25Cs. Obliczenia i badania bezpieczeństwa przejazdu wagonu przez tory wichrowate i własności biegowych wagonu towarowego należy wykonać w oparciu o raport ORE/ERRI B55Rp.8 [14], normę europejską PN-EN 14363:2007 [11] i kartę UIC 518 [6]. Należy wziąć pod uwagę, że obydwie sprężyny są częściami zamiennymi (wymiennymi) wg karty UIC 517 [5]. Zamienność części jest wymagana przez kartę UIC 510-1 [4], raport ORE/ERRI B12/Rp17 [13] oraz przepisy TSI [15].

\section{Obliczenia charakterystyki poprzecznej sprężyn wózków wagonów towarowych typu Y25L \\ 2.1. Model przyjęty do obliczeń}

Na rys. 1 przedstawiono układ zawieszenia Igo stopnia wózków Y25L, który przyjęto do obliczeń charakterystyki poprzecznej $\mathrm{k}_{\mathrm{y}}$ sprężyn śrubowych, korzystając ze wzorów Haringsa. Parametry sprężyn śrubowych tzn. sprężyny zewnętrznej oraz wewnętrznej przedstawiono w tabeli 1 zgodnie z kartą UIC 517 [4]. 


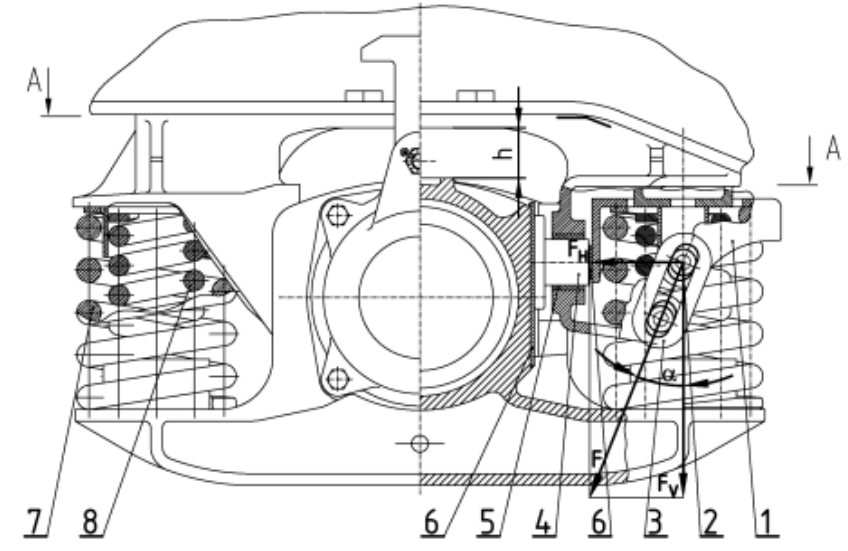

$A-A$

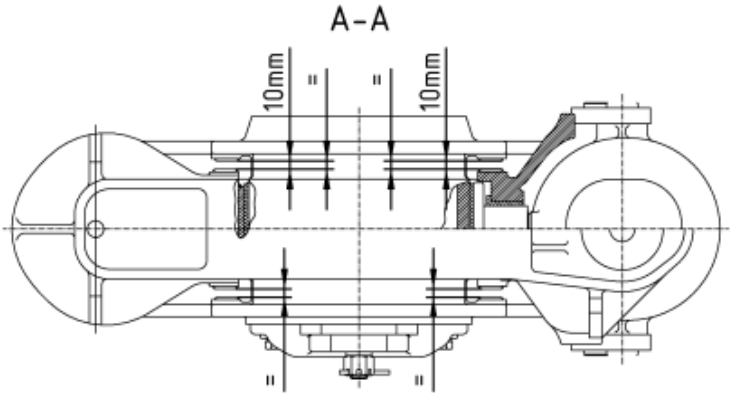

Legenda:

$\mathbf{1}$ - korpus dociskacza, 2 - czopiki, 3 - ogniwa, 4 - grzybek cierny, 5 - tulejka, 6 - plyta cierna,7 - sprężyna zewnętrzna, 8 - sprężyna wewnętrzna, $F, F_{V}, F_{H}$ - siła wypadkowa, siła pionowa, siła pozioma, $\alpha$ - kat pochylenia ogniwa, $h$-odlegtość do odbijaka

Rys.1. Usprężynowanie wózka Y25L (Y25C)

Parametry sprężyn przymaźnicznych wózków typu Y25L

\begin{tabular}{|c|c|c|c|c|c|}
\hline L.p. & Charakterystyka & Oznaczenie & $\begin{array}{c}\text { Jed- } \\
\text { nostka }\end{array}$ & $\begin{array}{c}\text { Sprężyna } \\
\text { ze- } \\
\text { wnętrzna }\end{array}$ & $\begin{array}{c}\text { Sprężyna } \\
\text { wewnętrzna }\end{array}$ \\
\hline 1. & Średnica drutu & $\mathrm{d}_{1}, \mathrm{~d}_{2}$ & $\mathrm{~mm}$ & 31 & 24,5 \\
\hline 2. & Średnica podziałowa & $\mathrm{D}_{1}, \mathrm{D}_{2}$ & $\mathrm{~mm}$ & 163 & 90 \\
\hline 3. & Całkowita ilość zwojów & $\mathrm{z}$ & - & 5,7 & 7,4 \\
\hline 4. & Ilość zwojów czynnych & $\mathrm{z}_{\mathrm{C}}$ & - & 4,2 & 5,9 \\
\hline 5. & $\begin{array}{l}\text { Wysokość w stanie } \\
\text { swobodnym }\end{array}$ & $\mathrm{H}_{0}$ & $\mathrm{~mm}$ & 260 & $234 \pm 2$ \\
\hline 6. & $\begin{array}{l}\text { Wysokość pod obciąże- } \\
\text { niem } 880 \text { daN }^{1)}\end{array}$ & $\mathrm{H}_{1}$ & $\mathrm{~mm}$ & $242_{-3}^{+1}$ & - \\
\hline 7. & Sztywność sprężyny & $\mathrm{k}_{1}, \mathrm{k}_{2}$ & $\begin{array}{c}\mathrm{daN} / \mathrm{m} \\
\mathrm{m}\end{array}$ & 49,80 & 82,17 \\
\hline 8. & Miękkość sprężyny & $\mathrm{c}_{1}, \mathrm{c}_{2}$ & $\mathrm{~mm} / \mathrm{kN}$ & 2,00 & 1,21 \\
\hline 9. & $\begin{array}{c}\text { Kierunek nawinięcia } \\
\text { zwojów }\end{array}$ & - & - & lewy & prawy \\
\hline
\end{tabular}

1) obciażenie dla sprężyny zewnętrznej, wynikajace z masy ekwiwalentnej wagonu równej $20000 \mathrm{~kg}$

Sztywność poprzeczną sprężyny zewnętrznej oraz wewnętrznej wyznacza się ze wzorów:

$$
\mathrm{k}_{\mathrm{YZ}}=\frac{\mathrm{P}_{\mathrm{Z1}}}{\frac{2}{\mathrm{q}}\left(1+\frac{\mathrm{P}_{\mathrm{Z} 1}}{\beta}\right) \cdot \operatorname{tg} \frac{\mathrm{q}_{1} \cdot \mathrm{H}_{1}}{2}-\mathrm{H}_{1}}
$$

Wyraz „q" wyznacza się ze wzoru:

$$
\mathrm{q}_{1}=\sqrt{\frac{\mathrm{P}_{\mathrm{Z} 1}}{\alpha_{1}} \cdot\left(1+\frac{\mathrm{P}_{\mathrm{Z} 1}}{\beta_{1}}\right)}
$$

Wyraz „ß” wyznacza się ze wzoru:

$$
\beta_{1}=0,324 \cdot \frac{\mathrm{H}_{1} \cdot \mathrm{d}_{1}{ }^{4} \cdot \mathrm{G}}{\mathrm{z}_{\mathrm{Cl}} \cdot \mathrm{D}_{1}{ }^{3}}
$$

Wyraz „ $\propto "$ wyznacza się ze wzoru:

$$
\alpha_{1}=0,0352 \cdot \frac{\mathrm{H}_{1} \cdot \mathrm{d}_{1}{ }^{4} \cdot \mathrm{G}}{\mathrm{z}_{\mathrm{Cl}} \cdot \mathrm{D}_{1}}
$$

gdzie:

$\mathrm{P}_{\mathrm{Z}}$ - obciążenie pionowe $[\mathrm{N}]$

$\mathrm{H}$ - wysokość sprężyny pod obciążeniem $\mathrm{P}_{\mathrm{Z}}[\mathrm{mm}]$

$\mathrm{G}$ - moduł Kirchoffa $\left[\mathrm{N} / \mathrm{mm}^{2}\right]$

\subsection{Wyznaczenie charakterystyki poprzecznej dla sprężyny zewnętrznej w stanie próżnym}

Efektywna wartość wysokości sprężyny $\mathrm{H}_{1}$ wynosi odpowiednio:

$$
\mathrm{H}_{1}=\mathrm{H}_{01}-1,5 \mathrm{~d}_{1}-\mathrm{f}_{1}
$$

gdzie:

$\mathrm{H}_{01}$ - wysokość sprężyny zewnętrznej w stanie próżnym wagonu

$\mathrm{d}_{1}$ - średnica drutu sprężyny zewnętrznej

$\mathrm{f}_{1}$ - strzałka ugięcia sprężyny zewnętrznej $\mathrm{w}$ stanie próżnym wagonu

Aby wyznaczyć wartość „, $\mathrm{k}_{\mathrm{y}}$ ” sprężyny śrubowej zewnętrznej, wyznaczono najpierw wartości $\alpha, \beta$ oraz q. Wstawiając $\mathrm{H}_{0}=260 \mathrm{~mm}, \mathrm{~d}_{1}=31 \mathrm{~mm}$ oraz $\mathrm{f}_{1}=17,67 \mathrm{~mm}$ do wzoru (5) otrzymuje

$$
\mathrm{H}_{1}=260-1,5 \cdot 31-17,67=195,83 \mathrm{~mm}
$$

Wstawiając wartości liczbowe do wzoru (3) czyli $\mathrm{H}_{1}=195,83 \mathrm{~mm}, \mathrm{~d}_{1}=31 \mathrm{~mm}, \mathrm{D}_{1}=163 \mathrm{~mm}, \mathrm{z}_{\mathrm{Cl}}=4,2$ oraz $\mathrm{G}=78480 \mathrm{~N} / \mathrm{mm}^{2}$ otrzymuje się:

$$
\beta_{1}=0,324 \cdot \frac{195,83 \cdot 31^{4} \cdot 78480}{4,2 \cdot 163^{3}}=252823,76 \mathrm{~N}
$$

Wstawiając wartości liczbowe do wzoru (4) czyli $\mathrm{H}_{1}=195,83 \mathrm{~mm}, \mathrm{~d}_{1}=31 \mathrm{~mm}, \mathrm{G}=78480 \mathrm{~N} / \mathrm{mm}^{2}$, $\mathrm{z}_{\mathrm{Cl}}=4,2, \mathrm{D}_{1}=163 \mathrm{~mm}$ oraz $\mathrm{G}=78480 \mathrm{~N} / \mathrm{mm}^{2}$ otrzymuje się:

$\alpha_{1}=0,0352 \cdot \frac{195,83 \cdot 31^{4} \cdot 78480}{4,2 \cdot 163}=729740726,3 \mathrm{~N} \cdot \mathrm{mm}^{2}$

Wstawiając wartości liczbowe do wzoru (2) czyli $\quad \mathrm{P}_{\mathrm{Zl}}=8800 \quad \mathrm{~N}, \quad \alpha_{1}=729740726,3 \mathrm{~N} ? \mathrm{~mm}^{2}$, $\beta_{1}=252727,12 \mathrm{~N}$ otrzymuje się:

$\mathrm{q}_{1}=\sqrt{\left(1+\frac{8800}{252727,12}\right) \frac{8800}{729740726,3}}=0,0035325594 \frac{1}{\mathrm{~mm}}$

Wstawiając $\alpha_{1}=729740726,3 \mathrm{~N} \cdot \mathrm{mm}^{2}$, $\beta_{1}=252823,76 \mathrm{~N}, \quad \mathrm{q}=0,0035325594 \quad 1 / \mathrm{mm} \quad$ oraz $\mathrm{P}_{\mathrm{Z1}}=8800 \mathrm{~N}$ do wzoru (1) otrzymuje się: 


$$
\mathrm{k}_{\mathrm{YZ}}=\frac{8800}{\frac{2}{0,0035325594}\left(1+\frac{8800}{252823,76}\right) \cdot \operatorname{tg} \frac{0,00352325594 \cdot 195,83}{2}-195,83}=598,58 \mathrm{~N} / \mathrm{mm}
$$

Jeśli przyjąć $\mathrm{H}_{1}=260-17,67 \mathrm{~mm}=242,33 \mathrm{~mm}$, wówczas obliczenia sztywności poprzecznej $\mathrm{k}_{\mathrm{YZ}}$ przyjmują postać przedstawioną poniżej. Wstawiając wartości liczbowe do wzoru (3) czyli $\mathrm{H}_{1}=242,33 \mathrm{~mm}, \mathrm{~d}_{1}=31 \mathrm{~mm}, \mathrm{D}_{1}=163 \mathrm{~mm}, \mathrm{z}_{\mathrm{Cl}}=4,2$ oraz $\mathrm{G}=78480 \mathrm{~N} / \mathrm{mm}^{2}$ otrzymuje się:

$$
\beta_{1}=0,324 \cdot \frac{242,33 \cdot 31^{4} \cdot 78480}{4,2 \cdot 163^{3}}=312856,98 \mathrm{~N}
$$

Wstawiając wartości liczbowe do wzoru (4) czyli $\mathrm{H}_{1}=242,33 \mathrm{~mm}, \mathrm{~d}_{1}=31 \mathrm{~mm}, \mathrm{G}=78480$ $\mathrm{N} / \mathrm{mm}^{2}, \mathrm{z}_{\mathrm{Cl}}=4,2, \mathrm{D}_{1}=163 \mathrm{~mm}$ oraz $\mathrm{G}=78480 \mathrm{~N} / \mathrm{mm}^{2}$ otrzymuje się:

$$
\alpha_{1}=0,0352 \cdot \frac{242,33 \cdot 31^{4} \cdot 78480}{4,2 \cdot 163}=903064397 \mathrm{~N} \cdot \mathrm{mm}^{2}
$$

Wstawiając wartości liczbowe do wzoru (2) czyli $\mathrm{P}_{\mathrm{Z1}}=8800 \mathrm{~N}, \alpha_{1}=903064397 \mathrm{~N} ? \mathrm{~mm}^{2}$, $\beta_{1}=312856,98 \mathrm{~N}$ otrzymuje się:

$$
\mathrm{q}_{1}=\sqrt{\left(1+\frac{8800}{312856,98}\right) \frac{8800}{903064397}}=0,00316523 \cdot \frac{1}{\mathrm{~mm}}
$$

Wstawiając $\alpha_{1}=903064397 \mathrm{~N} \cdot \mathrm{mm}^{2}, \beta_{1}=312856,98 \mathrm{~N}, \mathrm{q}=0,003165231 / \mathrm{mm}, \mathrm{H}_{1}=242,33 \mathrm{~mm}$ oraz $\mathrm{P}_{\mathrm{Z1}}=8800 \mathrm{~N}$ do wzoru (1) otrzymuje się:

$$
\mathrm{k}_{\mathrm{YZ1}}=\frac{8800}{\frac{2}{0,00316523}\left(1+\frac{8800}{312856,98}\right) \cdot \operatorname{tg} \frac{0,00316523 \cdot 242,33}{2}-242,33}=444,54 \mathrm{~N} / \mathrm{mm}
$$

2.3. Wyznaczenie charakterystyki poprzecznej dla sprężyny zewnętrznej w stanie ladownym

Efektywna wartość wysokości sprężyny $\mathrm{H}_{2 Z}$ wynosi odpowiednio:

$$
\mathrm{H}_{2 \mathrm{Z}}=\mathrm{H}_{01}-1,5 \mathrm{~d}_{1}-\mathrm{f}_{2}
$$

gdzie:

$\mathrm{H}_{2 Z}$ - wysokość sprężyny zewnętrznej w stanie ładownym

$\mathrm{f}_{2}$ - ugięcie sprężyny w stanie ładownym, wynosi $55,17 \mathrm{~mm}$ zgodnie $\mathrm{z}$ [1].

Wstawiając $\mathrm{H}_{01}=260 \mathrm{~mm}, \mathrm{~d}_{1}=31 \mathrm{~mm}$ oraz $\mathrm{f}=55,17 \mathrm{~mm}$ do wzoru (14) otrzymuje się:

$$
\mathrm{H}_{2 Z}=260-1,5 \cdot 31-55,17=158,33 \mathrm{~mm}
$$

Wstawiając wartości liczbowe do wzoru (3) czyli $\mathrm{H}_{2 Z}=158,33 \mathrm{~mm}, \mathrm{~d}_{1}=31 \mathrm{~mm}, \mathrm{D}_{1}=163 \mathrm{~mm}$, $\mathrm{z}_{\mathrm{C} 1}=4,2$ oraz $\mathrm{G}=78480 \mathrm{~N} / \mathrm{mm}^{2}$ otrzymuje się:

$$
\beta_{1}=0,324 \cdot \frac{158,33 \cdot 31^{4} \cdot 78480}{4,2 \cdot 163^{3}}=204409,88 \mathrm{~N}
$$

Wstawiając wartości liczbowe do wzoru (4) czyli $\mathrm{H}_{2 \mathrm{Z}}=158,33 \mathrm{~mm}, \mathrm{~d}_{1}=31 \mathrm{~mm}, \mathrm{G}=78480$ $\mathrm{N} / \mathrm{mm}^{2}, \mathrm{z}_{\mathrm{Cl}}=4,2, \mathrm{D}_{1}=163 \mathrm{~mm}$ oraz $\mathrm{G}=78480 \mathrm{~N} / \mathrm{mm}^{2}$ otrzymuje się:

$$
\alpha_{1}=0,0352 \cdot \frac{158,33 \cdot 31^{4} \cdot 78480}{4,2 \cdot 163}=590030891,6 \mathrm{~N} \cdot \mathrm{mm}^{2}
$$

Wstawiając wartości liczbowe do wzoru (2) czyli $\mathrm{P}_{\mathrm{Z} 2}=27475 \mathrm{~N}$, $\alpha_{1}=590030891,6 \mathrm{~N} ? \mathrm{~mm}^{2}, \beta_{1}=204409,88 \mathrm{~N}$ otrzymuje się:

$$
\mathrm{q}_{1}=\sqrt{\left(1+\frac{27475}{204409,88}\right) \frac{27475}{590030891,6}}=0,007268030642 \cdot \frac{1}{\mathrm{~mm}}
$$

Wstawiając $\alpha_{1}=590030891,6 \mathrm{~N} \cdot \mathrm{mm}^{2}, \beta_{1}=204409,88 \mathrm{~N}, \mathrm{q}=0,00726806421 / \mathrm{mm}, \mathrm{H}_{2}=158,33 \mathrm{~mm}$ oraz $\mathrm{P}_{\mathrm{Zz}}=27475 \mathrm{~N}$ do wzoru (1) otrzymuje się:

$$
\mathrm{k}_{\mathrm{YZ2}}=\frac{27475}{\frac{2}{0,0072680642}\left(1+\frac{27475}{204409,88}\right) \cdot \operatorname{tg} \frac{0,007268030642 \cdot 158,33}{2}-158,33}=622,56 \mathrm{~N} / \mathrm{mm}
$$

Jeśli przyjać $\mathrm{H}_{2 Z}=260-55,17 \mathrm{~mm}=204,83 \mathrm{~mm}$, wówczas obliczenia sztywności poprzecznej $\mathrm{k}_{\mathrm{YZ}}$ przyjmują postać, przedstawioną poniżej. Wstawiając wartości liczbowe do wzoru (3) czyli $\mathrm{H}_{2 Z}=204,83 \mathrm{~mm}, \mathrm{~d}_{1}=31 \mathrm{~mm}, \mathrm{D}_{1}=163 \mathrm{~mm}, \mathrm{z}_{\mathrm{Cl}}=4,2$ oraz $\mathrm{G}=78480 \mathrm{~N} / \mathrm{mm}^{2}$ otrzymuje się:

$$
\beta_{1}=0,324 \cdot \frac{204,83 \cdot 31^{4} \cdot 78480}{4,2 \cdot 163^{3}}=264443,101 \mathrm{~N}
$$


Wstawiając wartości liczbowe do wzoru (4) czyli $\mathrm{H}_{2 Z}=204,83 \mathrm{~mm}, \mathrm{~d}_{1}=31 \mathrm{~mm}, \mathrm{G}=78480$ $\mathrm{N} / \mathrm{mm}^{2}, \mathrm{z}_{\mathrm{Cl}}=4,2, \mathrm{D}_{1}=163 \mathrm{~mm}$ oraz $\mathrm{G}=78480 \mathrm{~N} / \mathrm{mm}^{2}$ otrzymuje się:

$$
\alpha_{1}=0,0352 \cdot \frac{204,83 \cdot 31^{4} \cdot 78480}{4,2 \cdot 163}=763317296,4 \mathrm{~N} \cdot \mathrm{mm}^{2}
$$

Wstawiając wartości liczbowe do wzoru (2) czyli $\mathrm{P}_{\mathrm{Zl}}=27475 \mathrm{~N}, \alpha_{1}=763317296,4 \mathrm{~N}^{2} \mathrm{~mm}^{2}$, $\beta_{1}=204409,88 \mathrm{~N}$ otrzymuje się:

$$
\mathrm{q}_{1}=\sqrt{\left(1+\frac{27475}{264443,101}\right) \frac{27475}{763317296,4}}=0,006303484524 \cdot \frac{1}{\mathrm{~mm}}
$$

Wstawiając $\alpha_{1}=763317296,4 \mathrm{~N} \cdot \mathrm{mm}^{2}, \beta_{1}=264443,101 \mathrm{~N}, \mathrm{q}=0,0085669730541 / \mathrm{mm}, \mathrm{H}_{2 Z}=204,83$ mm oraz $\mathrm{P}_{\mathrm{Zz}}=27475 \mathrm{~N}$ do wzoru (1) otrzymuje się:

$$
\mathrm{k}_{\mathrm{YZ2}}=\frac{27475}{\frac{2}{0,006303484524}\left(1+\frac{27475}{264443,101}\right) \cdot \operatorname{tg} \frac{0,006303484524 \cdot 204,83}{2}-204,83}=465,73 \mathrm{~N} / \mathrm{mm}
$$

\subsection{Wyznaczenie charakterystyki poprzecznej dla sprężyny zewnętrznej w stanie pracy dyna-} micznej

Efektywna wartość wysokości sprężyny $\mathrm{H}_{3 Z}$ wynosi odpowiednio:

$$
\mathrm{H}_{3 Z}=\mathrm{H}_{0 Z}-1,5 \mathrm{~d}_{1}-\mathrm{f}_{2}-\mathrm{f}_{3}
$$

gdzie:

$\mathrm{H}_{3 Z^{-}}$wysokość sprężyny w stanie maksymalnego ugięcia w wyniku pracy dynamicznej

$\mathrm{f}_{2}$ - strzałka ugięcia $\mathrm{w}$ stanie ładownym, wynosi $55 \mathrm{~mm}$ zgodnie $\mathrm{z}$ [1]

$\mathrm{f}_{3}$ - strzałka ugięcia w stanie pracy dynamicznej.

Wstawiając $\mathrm{H}_{01}=260 \mathrm{~mm}, \mathrm{~d}_{1}=31 \mathrm{~mm}$ oraz $\mathrm{f}=55,17 \mathrm{~mm}$ do wzoru (24) otrzymuje się:

$$
\mathrm{H}_{3 \mathrm{Z}}=260-1,5 \cdot 31-55,17-11,7=146,63 \mathrm{~mm}
$$

Wstawiając wartości liczbowe do wzoru (3) czyli $\mathrm{H}_{1}=146,63 \mathrm{~mm}, \mathrm{~d}_{1}=31 \mathrm{~mm}, \mathrm{D}_{1}=163 \mathrm{~mm}$, $\mathrm{z}_{\mathrm{C} 1}=4,2$ oraz $\mathrm{G}=78480 \mathrm{~N} / \mathrm{mm}^{2}$ otrzymuje się:

$$
\beta_{1}=0,324 \cdot \frac{146,63 \cdot 31^{4} \cdot 78480}{4,2 \cdot 163^{3}}=1893047,498 \mathrm{~N}
$$

Wstawiając wartości liczbowe do wzoru (4) czyli $\mathrm{H}_{3 \mathrm{Z}}=146,63 \mathrm{~mm}, \mathrm{~d}_{1}=31 \mathrm{~mm}, \mathrm{z}_{\mathrm{Cl}}=4,2$, $D_{1}=163 \mathrm{~mm}$ oraz $\mathrm{G}=78480 \mathrm{~N} / \mathrm{mm}^{2}$ otrzymuje się:

$$
\alpha_{1}=0,0352 \cdot \frac{146,63 \cdot 31^{4} \cdot 78480}{4,2 \cdot 163}=546429796,3 \mathrm{~N} \cdot \mathrm{mm}^{2}
$$

Wstawiając wartości liczbowe do wzoru (2) czyli $\mathrm{P}_{\mathrm{Z3}}=33301,6 \mathrm{~N}, \alpha_{1}=546429796,3 \mathrm{Nmm}^{2}$, $\beta_{1}=189304,7498 \mathrm{~N}$ otrzymuje się:

$$
\mathrm{q}_{1}=\sqrt{\left(1+\frac{33301,6}{189304,7498}\right) \frac{33301,6}{546429796,3}}=0,008465514974 \cdot \frac{1}{\mathrm{~mm}}
$$

Wstawiając $\quad \alpha_{1}=546243466,8 \mathrm{~N} \cdot \mathrm{mm}^{2}, \quad \beta_{1}=189304,7498 \mathrm{~N}, \quad \mathrm{q}=0,008465514974 \quad 1 / \mathrm{mm}$, $\mathrm{H}_{3 \mathrm{Z}}=146,63 \mathrm{~mm}$ oraz $\mathrm{P}_{\mathrm{Zz}}=33301,6 \mathrm{~N}$ do wzoru (1) otrzymuje się:

$$
\mathrm{k}_{\mathrm{YZ3}}=\frac{2}{\frac{2}{0,008465514974}\left(1+\frac{33301,6}{189304,7498}\right) \cdot \operatorname{tg} \frac{0,008465514974 \cdot 146,63}{2}-146,63}=640,71 \mathrm{~N} / \mathrm{mm}
$$

Jeśli przyjąć $\mathrm{H}_{3 Z}=260-55,17 \mathrm{~mm}-11,7 \mathrm{~mm}=193,13 \mathrm{~mm}$, wówczas obliczenia sztywności poprzecznej kyz przyjmują postać, przedstawioną poniżej. Wstawiając wartości liczbowe do wzoru (3) czyli $\mathrm{H}_{3 \mathrm{Z}}=193,13 \mathrm{~mm}, \mathrm{~d}_{1}=31 \mathrm{~mm}, \mathrm{D}_{1}=163 \mathrm{~mm}, \mathrm{z}_{\mathrm{Cl}}=4,2$ oraz $\mathrm{G}=78480 \mathrm{~N} / \mathrm{mm}^{2}$ otrzymuje się:

$$
\begin{gathered}
\beta_{1}=0,324 \cdot \frac{193,13 \cdot 31^{4} \cdot 78480}{4,2 \cdot 163^{3}}=249337,9686 \mathrm{~N} \\
\alpha_{1}=0,0352 \cdot \frac{193,13 \cdot 31^{4} \cdot 78480}{4,2 \cdot 163}=719716201 \mathrm{~N} \cdot \mathrm{mm}^{2}
\end{gathered}
$$

Wstawiając wartości liczbowe do wzoru (2) czyli $\mathrm{P}_{\mathrm{Z3}}=33301,6 \quad \mathrm{~N}$, $\alpha_{1}=719716201 \mathrm{Nmm}^{2}$, 
$\beta_{1}=249337,968 \mathrm{~N}$ otrzymuje się:

$$
\mathrm{q}_{1}=\sqrt{\left(1+\frac{33301,6}{249337,9686}\right) \frac{33301,6}{719716201}}=0,007242261181 \cdot \frac{1}{\mathrm{~mm}}
$$

Wstawiając $\alpha_{1}=719716201 \mathrm{~N} \cdot \mathrm{mm}^{2}, \beta_{1}=249337,9686 \mathrm{~N}, \mathrm{q}=0,0072422611811 / \mathrm{mm}, \mathrm{H}_{3 Z}=193,13$ $\mathrm{mm}$ oraz $\mathrm{P}_{\mathrm{Z} 2}=33301,6 \mathrm{~N}$ do wzoru (1) otrzymuje się:

$$
\mathrm{k}_{\mathrm{YZ3}}=\frac{33301,6}{\frac{2}{0,00724226181}\left(1+\frac{33301,6}{249337,9686}\right) \cdot \operatorname{tg} \frac{0,007242261181 \cdot 193,13}{2}-193,13}=474,43 \mathrm{~N} / \mathrm{mm}
$$

2.4. Wyznaczenie charakterystyki poprzecznej dla sprężyny zewnętrznej $w$ stanie pracy dynamicznej (zerowy luz na odbijaku)

Efektywna wartość wysokości sprężyny $\mathrm{H}_{2}$ wynosi odpowiednio:

$$
\mathrm{H}_{4 Z}=\mathrm{H}_{01}-\mathrm{f}_{1}-1,5 \mathrm{~d}_{1}-\mathrm{f}_{4}
$$

gdzie:

$\mathrm{H}_{4 Z^{-}}$wysokość sprężyny w stanie maksymalnego ugięcia, aż do odbijaka $\mathrm{f}_{4}$ - strzałka ugięcia aż do osiagnięcia odbijaka, $60 \mathrm{~mm}$

Wstawiając $\mathrm{H}_{0}=260 \mathrm{~mm}, \mathrm{~d}_{1}=31 \mathrm{~mm}, \mathrm{f}_{1}=16,67$ oraz $\mathrm{f}_{4}=60 \mathrm{~mm}$ do wzoru (24) otrzymuje się:

$$
\mathrm{H}_{4 \mathrm{Z}}=260-1,5 \cdot 31-17,67-60=135,83 \mathrm{~mm}
$$

Wstawiając wartości liczbowe do wzoru (3) czyli $\mathrm{H}_{1}=135,83 \mathrm{~mm}, \mathrm{~d}_{1}=31 \mathrm{~mm}, \mathrm{D}_{1}=163$ $\mathrm{mm}, \mathrm{z}_{\mathrm{C} 1}=4,2$ oraz $\mathrm{G}=78480 \mathrm{~N} / \mathrm{mm}^{2}$ otrzymuje się:

$$
\beta_{1}=0,324 \cdot \frac{135,83 \cdot 31^{4} \cdot 78480}{4,2 \cdot 163^{3}}=175361,5506 \mathrm{~N}
$$

Wstawiając wartości liczbowe do wzoru (4) czyli $\mathrm{H}_{4 \mathrm{Z}}=135,83 \mathrm{~mm}, \mathrm{~d}_{1}=31 \mathrm{~mm}, \mathrm{z}_{\mathrm{Cl}}=4,2$, $D_{1}=163 \mathrm{~mm}$ oraz $\mathrm{G}=78480 \mathrm{~N} / \mathrm{mm}^{2}$ otrzymuje się:

$$
\alpha_{1}=0,0352 \cdot \frac{135,83 \cdot 31^{4} \cdot 78480}{4,2 \cdot 163}=506182631,3 \mathrm{~N} \cdot \mathrm{mm}^{2}
$$

Wstawiając wartości liczbowe do wzoru (2) czyli $\mathrm{P}_{\mathrm{Zl}}=38680 \mathrm{~N}, \alpha_{1}=506182631,3 \mathrm{Nmm}^{2}$, $\beta_{1}=175361,5506 \mathrm{~N}$ otrzymuje się:

$$
\mathrm{q}_{1}=\sqrt{\left(1+\frac{38680}{175361,5506}\right) \frac{38680}{506182631,3}}=0,009657650149 \cdot \frac{1}{\mathrm{~mm}}
$$

Wstawiając $\alpha_{1}=506182631,3 \cdot \mathrm{mm}^{2}, \beta_{1}=175361,5506 \mathrm{~N}, \mathrm{q}=0,0096576501491 / \mathrm{mm}, \mathrm{H}_{4 \mathrm{Z}}=135,83$ $\mathrm{mm}$ oraz $\mathrm{P}_{\mathrm{Z} 4}=38680 \mathrm{~N}$ do wzoru (1) otrzymuje się:

$$
\mathrm{k}_{\mathrm{YZ4}}=\frac{38680}{\frac{2}{0,009657650149}\left(1+\frac{38680}{175361,5506}\right) \cdot \operatorname{tg} \frac{0,009657650149 \cdot 135,83}{2}-135,83}=659,06 \mathrm{~N} / \mathrm{mm}
$$

Jeśli przyjąć $\mathrm{H}_{4 Z}=260-17,67-60=182,33 \mathrm{~mm}$, wówczas obliczenia sztywności poprzecznej $\mathrm{k}_{\mathrm{YZ}}$ przyjmują postać, przedstawioną poniżej. Wstawiając wartości liczbowe do wzoru (3) czyli $\mathrm{H}_{4 \mathrm{Z}}=182,33 \mathrm{~mm}, \mathrm{~d}_{1}=31 \mathrm{~mm}, \mathrm{D}_{1}=163 \mathrm{~mm}, \mathrm{z}_{\mathrm{Cl}}=4,2$ oraz $\mathrm{G}=78480 \mathrm{~N} / \mathrm{mm}^{2}$ otrzymuje się:

$$
\beta_{1}=0,324 \cdot \frac{182,33 \cdot 31^{4} \cdot 78480}{4,2 \cdot 163^{3}}=235394,76 \mathrm{~N}
$$

Wstawiając wartości liczbowe do wzoru (4) czyli $\mathrm{H}_{4 \mathrm{Z}}=182,33 \mathrm{~mm}, \mathrm{~d}_{1}=31 \mathrm{~mm}, \mathrm{z}_{\mathrm{Cl}}=4,2$, $\mathrm{D}_{1}=163 \mathrm{~mm}$ oraz $\mathrm{G}=78480 \mathrm{~N} / \mathrm{mm}^{2}$ otrzymuje się:

$$
\alpha_{1}=0,0352 \cdot \frac{182,33 \cdot 31^{4} \cdot 78480}{4,2 \cdot 163}=679469036 \mathrm{~N} \cdot \mathrm{mm}^{2}
$$

Wstawiając wartości liczbowe do wzoru (2) czyli $\mathrm{P}_{\mathrm{Z} 4}=38680 \mathrm{~N}, \alpha_{1}=679469036 \mathrm{Nmm}^{2}$, $\beta_{1}=235394,76 \mathrm{~N}$ otrzymuje się:

$$
\mathrm{q}_{1}=\sqrt{\left(1+\frac{38680}{235394,76}\right) \frac{38680}{679469036}}=0,008141314338 \cdot \frac{1}{\mathrm{~mm}}
$$

Wstawiając $\alpha_{1}=679469036 \mathrm{~N} \cdot \mathrm{mm}^{2}, \beta_{1}=235394,76 \mathrm{~N}, \mathrm{q}=0,0081413143381 / \mathrm{mm}, \mathrm{H}_{4 Z}=182,33$ $\mathrm{mm}$ oraz $\mathrm{P}_{\mathrm{Z} 4}=38680 \mathrm{~N}$ do wzoru (1) otrzymuje się: 


$$
\mathrm{k}_{\mathrm{YZ4}}=\frac{38680}{\frac{2}{0,008141314338}\left(1+\frac{38680}{235394,76}\right) \cdot \operatorname{tg} \frac{0,008141314338 \cdot 182,33}{2}-182,33}=483,52 \mathrm{~N} / \mathrm{mm}
$$

\subsection{Wyznaczenie charakterystyki poprzecznej dla sprężyny wewnętrznej w stanie ładownym}

Efektywna wartość wysokości sprężyny $\mathrm{H}_{2 \mathrm{~W}}$ wynosi odpowiednio:

$$
\mathrm{H}_{2 \mathrm{~W}}=\mathrm{H}_{0 \mathrm{~W}}-1,5 \mathrm{~d}_{1}-\mathrm{f}_{2 \mathrm{~W}}
$$

Po wstawieniu wartości: $\mathrm{H}_{\mathrm{OW}}-234 \mathrm{~mm}, \mathrm{f}_{2 \mathrm{~W}}=29,5 \mathrm{~mm}$ oraz $\mathrm{d}_{1}=24,5 \mathrm{~mm}$ do wzoru (44) otrzymuje się:

$$
\mathrm{H}_{2 \mathrm{~W}}=234-1,5 \cdot 24,5-29,5=167,75 \mathrm{~mm}
$$

Wstawiając wartości liczbowe do wzoru (3) czyli $\mathrm{H}_{2 \mathrm{~W}}=167,75 \mathrm{~mm}, \mathrm{~d}_{2}=24,5 \mathrm{~mm}, \mathrm{D}_{2}=90 \mathrm{~mm}$, $\mathrm{z}_{\mathrm{C} 2}=5,9$ oraz $\mathrm{G}=78480 \mathrm{~N} / \mathrm{mm}^{2}$ otrzymuje się:

$$
\beta_{1}=0,324 \cdot \frac{167,75 \cdot 24,5^{4} \cdot 78480}{5,9 \cdot 90^{3}}=357178,4798 \mathrm{~N}
$$

Wstawiając wartości liczbowe do wzoru (4) czyli $\mathrm{H}_{2 \mathrm{~W}}=167,75 \mathrm{~mm}, \mathrm{~d}_{2}=24,5 \mathrm{~mm}, \mathrm{z}_{\mathrm{Cl}}=5,9$, $\mathrm{D}_{2}=90 \mathrm{~mm}$ oraz $\mathrm{G}=78480 \mathrm{~N} / \mathrm{mm}^{2}$ otrzymuje się:

$$
\alpha_{1}=0,0352 \cdot \frac{167,75 \cdot 24,5^{4} \cdot 78480}{5,9 \cdot 90}=314437259,9 \mathrm{~N} \cdot \mathrm{mm}^{2}
$$

Wstawiając wartości liczbowe do wzoru (2) czyli $\mathrm{P}_{\mathrm{Zl}}=24240 \mathrm{~N}, \alpha_{1}=314437259,9 \mathrm{Nmm}^{2}$, $\beta_{1}=357178,4798$ otrzymuje się:

$$
\mathrm{q}_{1}=\sqrt{\left(1+\frac{24240}{357178,4798}\right) \frac{24240}{314437259,9}}=0,009073138271 \cdot \frac{1}{\mathrm{~mm}}
$$

Wstawiając $\quad \alpha_{1}=314437259,9 \mathrm{~N} \cdot \mathrm{mm}^{2}, \quad \beta_{1}=357178,4798 \mathrm{~N}, \quad \mathrm{q}=0,00907318271 \quad 1 / \mathrm{mm}$, $\mathrm{H}_{2 \mathrm{~W}}=167,75 \mathrm{~mm}$ oraz $\mathrm{P}_{\mathrm{Z} 2}=24240 \mathrm{~N}$ do wzoru (1) otrzymuje się:

$$
\mathrm{k}_{\mathrm{YW} 2}=\frac{2}{\frac{2}{0,00907314338}\left(1+\frac{24240}{357178,4798}\right) \cdot \operatorname{tg} \frac{0,009073118271 \cdot 167,75}{2}-167,75}=429,56 \mathrm{~N} / \mathrm{mm}
$$

Jeśli przyjąć $\mathrm{H}_{2 \mathrm{~W}}=234-29,5=204,5 \mathrm{~mm}$, wówczas obliczenia sztywności poprzecznej $\mathrm{k}_{\mathrm{YZ}}$ przyjmują postać, przedstawioną poniżej. Wstawiając wartości liczbowe do wzoru (3) czyli $\mathrm{H}_{2 \mathrm{~W}}=234$ $29,5=204,5 \mathrm{~mm}, \mathrm{~d}_{2}=24,5 \mathrm{~mm}, \mathrm{D}_{2}=90 \mathrm{~mm}, \mathrm{z}_{\mathrm{C} 2}=5,9$ oraz $\mathrm{G}=78480 \mathrm{~N} / \mathrm{mm}^{2}$ otrzymuje się:

$$
\beta_{1}=0,324 \cdot \frac{204,5 \cdot 24,5^{4} \cdot 78480}{5,9 \cdot 90^{3}}=435594,2261 \mathrm{~N}
$$

Wstawiając wartości liczbowe do wzoru (4) czyli $\mathrm{H}_{2 \mathrm{~W}}=204,5 \mathrm{~mm}, \mathrm{~d}_{2}=24,5 \mathrm{~mm}, \mathrm{z}_{\mathrm{Cl}}=5,9$, $\mathrm{D}_{2}=90 \mathrm{~mm}$ oraz $\mathrm{G}=78480 \mathrm{~N} / \mathrm{mm}^{2}$ otrzymuje się:

$$
\alpha_{1}=0,0352 \cdot \frac{204,5 \cdot 24,5^{4} \cdot 78480}{5,9 \cdot 90}=383322918,9 \mathrm{~N} \cdot \mathrm{mm}^{2}
$$

Wstawiając wartości liczbowe do wzoru (2) czyli $\mathrm{P}_{\mathrm{W} 2}=24240 \mathrm{~N}, \alpha_{1}=435594,2261 \mathrm{Nmm}^{2}$, $\beta_{1}=383322918,9$ otrzymuje się:

$$
\mathrm{q}_{1}=\sqrt{\left(1+\frac{24240}{435594,2261}\right) \frac{24240}{383322918,9}}=0,00817040348 \cdot \frac{1}{\mathrm{~mm}}
$$

Wstawiając $\alpha_{1}=383322918,9 \mathrm{~N} \cdot \mathrm{mm}^{2}, \beta_{1}=435594,2261 \mathrm{~N}, \mathrm{q}=0,00817043481 / \mathrm{mm}, \mathrm{H}_{2 \mathrm{~W}}=204,5$ $\mathrm{mm}$ oraz $\mathrm{P}_{\mathrm{W} 2}=24240 \mathrm{~N}$ do wzoru (1) otrzymuje się:

$$
\mathrm{k}_{\mathrm{YW} 2}=\frac{24240}{\frac{2}{0,00817040348}\left(1+\frac{24240}{383322918,9}\right) \cdot \operatorname{tg} \frac{0,00817040348 \cdot 204,5}{2}-204,5}=365,82 \mathrm{~N} / \mathrm{mm}
$$

2.6. Wyznaczenie charakterystyki poprzecznej dla sprężyny wewnętrznej w stanie pracy dynamicznej

Efektywna wartość wysokości sprężyny $\mathrm{H}_{2 \mathrm{~W}}$ wynosi odpowiednio:

$$
\mathrm{H}_{3 \mathrm{~W}}=\mathrm{H}_{0 \mathrm{~W}}-1,5 \mathrm{~d}_{2}-\mathrm{f}_{2 \mathrm{~W}}-\mathrm{f}_{3 \mathrm{~W}}
$$


Po wstawieniu wartości liczbowych $\mathrm{H}_{\mathrm{OW}}=234 \mathrm{~mm}, \mathrm{~d}_{2}=24,5 \mathrm{~mm}$ oraz $\mathrm{f}_{3 \mathrm{~W}}=11,7 \mathrm{~mm}$ otrzymuje się:

$$
\mathrm{H}_{3 \mathrm{~W}}=234-1,5 \cdot 24,5-29,5-11,7=156,05 \mathrm{~mm}
$$

$\mathrm{z}_{\mathrm{C} 2}=5,9$ oraz $\mathrm{G}=78480 \mathrm{~N} / \mathrm{mm}^{2}$ otrzymuje się:

$$
\beta_{1}=0,324 \cdot \frac{156,05 \cdot 24,5^{4} \cdot 78480}{5,9 \cdot 90^{3}}=332393,54 \mathrm{~N}
$$

Wstawiając wartości liczbowe do wzoru (4) czyli $\mathrm{H}_{3 \mathrm{~W}}=156,05 \mathrm{~mm}, \mathrm{~d}_{2}=24,5 \mathrm{~mm}, \mathrm{z}_{\mathrm{Cl}}=5,9$, $\mathrm{D}_{2}=90 \mathrm{~mm}$ oraz $\mathrm{G}=78480 \mathrm{~N} / \mathrm{mm}^{2}$ otrzymuje się:

$$
\alpha_{1}=0,0352 \cdot \frac{156,05 \cdot 24,5^{4} \cdot 78480}{5,9 \cdot 90}=292506315 \mathrm{~N} \cdot \mathrm{mm}^{2}
$$

Wstawiając wartości liczbowe do wzoru (2) czyli $\mathrm{P}_{3 \mathrm{~W}}=33853,89 \mathrm{~N}, \alpha_{1}=292506315$ $\mathrm{Nmm}^{2}, \beta_{1}=332393,54$ otrzymuje się:

$$
\mathrm{q}_{1}=\sqrt{\left(1+\frac{33853,89}{332393,54}\right) \frac{33853,89}{292506315}}=0,011292696 \cdot \frac{1}{\mathrm{~mm}}
$$

Wstawiając $\alpha_{1}=292506315 \mathrm{~N} \cdot \mathrm{mm}^{2}, \beta_{1}=332393,54 \mathrm{~N}, \mathrm{q}=0,0112926961 / \mathrm{mm}, \mathrm{H}_{3 \mathrm{~W}}=156,5 \mathrm{~mm}$ oraz $\mathrm{P}_{\mathrm{W} 3}=24240 \mathrm{~N}$ do wzoru (1) otrzymuje się:

$$
\mathrm{k}_{\mathrm{YW} 3}=\frac{33853,89}{\frac{2}{0,011292696}\left(1+\frac{33853,89}{332393,54}\right) \cdot \operatorname{tg} \frac{0,011292696 \cdot 156,05}{2}-156,05}=420,78 \mathrm{~N} / \mathrm{mm}
$$

Jeśli przyjąć $\mathrm{H}_{3 \mathrm{~W}}=\mathrm{H}_{0 \mathrm{~W}}-\mathrm{f}_{2 \mathrm{~W}}-\mathrm{f}_{3 \mathrm{~W}} \mathrm{~mm}$, wówczas obliczenia sztywności poprzecznej $\mathrm{k}_{\mathrm{YZ}}$ przyjmują postać, przedstawioną poniżej. Po wstawieniu wartości liczbowych do wzoru (3) $\mathrm{H}_{3 \mathrm{~W}}=234$ $29,5-11,7=192,8 \mathrm{~mm}, \mathrm{~d}_{2}=24,5 \mathrm{~mm}, \mathrm{z}_{\mathrm{Cl}}=5,9, \mathrm{D}_{2}=90 \mathrm{~mm}$ oraz $\mathrm{G}=78480 \mathrm{~N} / \mathrm{mm}^{2}$ otrzymuje się:

$$
\beta_{1}=0,324 \cdot \frac{192,8 \cdot 24,5^{4} \cdot 78480}{5,9 \cdot 90^{3}}=410672,6982 \mathrm{~N}
$$

Wstawiając wartości liczbowe do wzoru (4) czyli $\mathrm{H}_{3 \mathrm{~W}}=192,8 \mathrm{~mm}, \mathrm{~d}_{2}=24,5 \mathrm{~mm}, \mathrm{z}_{\mathrm{Cl}}=5,9$, $\mathrm{D}_{2}=90 \mathrm{~mm}$ oraz $\mathrm{G}=78480 \mathrm{~N} / \mathrm{mm}^{2}$ otrzymuje się:

$$
\alpha_{1}=0,0352 \cdot \frac{192,8 \cdot 24,5^{4} \cdot 78480}{5,9 \cdot 90}=361391974,1 \mathrm{~N} \cdot \mathrm{mm}^{2}
$$

Wstawiając wartości liczbowe do wzoru (2) czyli $\mathrm{P}_{\mathrm{W} 3}=33853,89 \mathrm{~N}, \alpha_{1}=361391974,1 \mathrm{Nmm}^{2}$, $\beta_{1}=$ otrzymuje się:

$$
\mathrm{q}_{1}=\sqrt{\left(1+\frac{33853,89}{410672,6982}\right) \frac{33853,89}{361391974,1}}=0,01012616 \cdot \frac{1}{\mathrm{~mm}}
$$

Wstawiając wartości liczbowe do wzoru (1) czyli: $q_{1}=0,010047725, P_{w_{3}}=33853,89 \mathrm{~N}$, $\mathrm{H}_{3 \mathrm{~W}}=192,8 \mathrm{~mm}_{1}=361391974,1 \mathrm{Nmm}^{2}, \beta_{1}=410672,6982$ otrzymuje się:

$$
\mathrm{k}_{\mathrm{YW} 3}=\frac{33853,89}{\frac{2}{0,01012616}\left(1+\frac{33853,89}{410672,6982}\right) \cdot \operatorname{tg} \frac{0,01012616 \cdot 192,8}{2}-192,8}=274,51 \mathrm{~N} / \mathrm{mm}
$$

\subsection{Wyznaczenie charakterystyki poprzecznej dla sprężyny wewnętrznej w stanie pracy dyna-} micznej aż do odbijaka

Efektywna wartość wysokości sprężyny $\mathrm{H}_{2 \mathrm{w}}$ wynosi odpowiednio:

$$
\mathrm{H}_{4 \mathrm{~W}}=\mathrm{H}_{0 \mathrm{~W}}-1,5 \mathrm{~d}_{2}-\mathrm{f}_{4 \mathrm{~W}}
$$

Po wstawieniu wartości liczbowych $\mathrm{H}_{\mathrm{OW}}=234 \mathrm{~mm}, \mathrm{~d}_{2}=24,5 \mathrm{~mm}$ oraz $\mathrm{f}_{3 \mathrm{~W}}=11,7 \mathrm{~mm}$ otrzymuje się:

$$
\mathrm{H}_{4 \mathrm{w}}=234-1,5 \cdot 24,5-52=145,25 \mathrm{~mm}
$$

Wstawiając wartości liczbowe do wzoru (3) czyli $\mathrm{H}_{2 \mathrm{~W}}=145,25 \mathrm{~mm}, \mathrm{~d}_{2}=24,5 \mathrm{~mm}, \mathrm{D}_{2}=90 \mathrm{~mm}$, $\mathrm{z}_{\mathrm{C} 2}=5,9$ oraz $\mathrm{G}=78480 \mathrm{~N} / \mathrm{mm}^{2}$ otrzymuje się:

$$
\beta_{1}=0,324 \cdot \frac{145,25 \cdot 24,5^{4} \cdot 78480}{5,9 \cdot 90^{3}}=309389,053 \mathrm{~N}
$$


Wstawiając wartości liczbowe do wzoru (4) czyli $\mathrm{H}_{2 \mathrm{~W}}=156,05 \mathrm{~mm}, \mathrm{~d}_{2}=24,5 \mathrm{~mm}, \mathrm{z}_{\mathrm{Cl}}=5,9$, $\mathrm{D}_{2}=90 \mathrm{~mm}$ oraz $\mathrm{G}=78480 \mathrm{~N} / \mathrm{mm}^{2}$ otrzymuje się:

$$
\alpha_{1}=0,0352 \cdot \frac{145,25 \cdot 24,5^{4} \cdot 78480}{5,9 \cdot 90}=272262366,6 \mathrm{~N} \cdot \mathrm{mm}^{2}
$$

Wstawiając wartości liczbowe do wzoru (2) czyli $\mathrm{P}_{\mathrm{W} 4}=42730 \mathrm{~N}, \alpha_{1}=272262366,6 \mathrm{Nmm}^{2}$, $\beta_{1}=309389,053$ otrzymuje się:

$$
\mathrm{q}_{1}=\sqrt{\left(1+\frac{42730}{309389,053}\right) \frac{42730}{272262366,6}}=0,013364875 \frac{1}{\mathrm{~mm}}
$$

Wstawiając wartości liczbowe do wzoru (1) czyli: $\mathrm{q}_{1}=0,013364875, \mathrm{P}_{\mathrm{W} 4}=42730 \mathrm{~N}$,

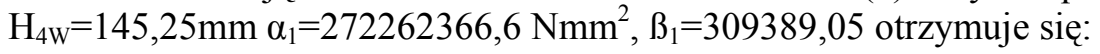

$$
\mathrm{k}_{\mathrm{YW} 4}=\frac{42730}{\frac{2}{0,013364875}\left(1+\frac{42730}{309389,05}\right) \cdot \operatorname{tg} \frac{0,013364875 \cdot 145,25}{2}-145,25}=412,43 \mathrm{~N} / \mathrm{mm}
$$

Jeśli przyjąć $\mathrm{H}_{3 \mathrm{~W}}=\mathrm{H}_{0 \mathrm{~W}}-\mathrm{f}_{2 \mathrm{~W}}-\mathrm{f}_{3 \mathrm{~W}} \quad \mathrm{~mm}$, wówczas obliczenia sztywności poprzecznej $\mathrm{k}_{\mathrm{YZ}}$ przyjmują postać, przedstawioną poniżej.

Wstawiając wartości liczbowe do wzoru (3) czyli $\mathrm{H}_{4 \mathrm{w}}=182 \mathrm{~mm}, \mathrm{~d}_{2}=24,5 \mathrm{~mm}, \mathrm{D}_{2}=90 \mathrm{~mm}$, $\mathrm{z}_{\mathrm{C} 2}=5,9$ oraz $\mathrm{G}=78480 \mathrm{~N} / \mathrm{mm}^{2}$ otrzymuje się:

$$
\beta_{1}=0,324 \cdot \frac{182 \cdot 24,5^{4} \cdot 78480}{5,9 \cdot 90^{3}}=387668,211 \mathrm{~N}
$$

Wstawiając wartości liczbowe do wzoru (4) czyli $\mathrm{H}_{4 \mathrm{~W}}=182 \mathrm{~mm}, \mathrm{~d}_{2}=24,5 \mathrm{~mm}, \mathrm{z}_{\mathrm{Cl}}=5,9, \mathrm{D}_{2}=90$ $\mathrm{mm}$ oraz $\mathrm{G}=78480 \mathrm{~N} / \mathrm{mm}^{2}$ otrzymuje się:

$$
\alpha_{1}=0,0352 \cdot \frac{182 \cdot 24,5^{4} \cdot 78480}{5,9 \cdot 90}=341148025,7 \mathrm{~N} \cdot \mathrm{mm}^{2}
$$

Wstawiając wartości liczbowe do wzoru (2) czyli $\mathrm{P}_{\mathrm{W} 4}=42730 \mathrm{~N}, \alpha_{1}=341148025,7 \mathrm{Nmm}^{2}$, $\beta_{1}=387668,211$ otrzymuje się:

$$
\mathrm{q}_{1}=\sqrt{\left(1+\frac{42730}{387668,211}\right) \frac{42730}{341148025,7}}=0,011792344 \frac{1}{\mathrm{~mm}}
$$

Wstawiając wartości liczbowe do wzoru (1) czyli: $\mathrm{q}_{1}=0,011792344, \quad \mathrm{P}_{\mathrm{W} 4}=42730 \mathrm{~N}$, $\mathrm{H}_{4 \mathrm{~W}}=182 \mathrm{~mm}, \alpha_{1}=341148025,7 \mathrm{Nmm}^{2}, \beta_{1}=387668,211$ otrzymuje się:

\begin{tabular}{|c|c|c|c|}
\hline \multicolumn{2}{|c|}{ Sprężyna zewnętrzna } & \multicolumn{2}{|c|}{ Sprężyna wewnętrzna } \\
\hline \multicolumn{4}{|c|}{ SZTYWNOŚĆ POPRZECZNA } \\
\hline $\begin{array}{c}\text { Bez uwzględnienia zwojów } \\
\text { biernych }\end{array}$ & $\begin{array}{c}\mathrm{Z} \text { uwzględnieniem zwojów } \\
\text { biernych }\end{array}$ & $\begin{array}{c}\text { Bez uwzględnienia zwojów } \\
\text { biernych }\end{array}$ & $\begin{array}{c}\mathrm{Z} \text { uwzględnieniem zwojów } \\
\text { biernych }\end{array}$ \\
\hline \multicolumn{4}{|c|}{ STAN PRÓŻNY WAGONU TOWAROWEGO } \\
\hline $598,58 \mathrm{~N} / \mathrm{mm}$ & $444,54 \mathrm{~N} / \mathrm{mm}$ & 0 & 0 \\
\hline \multicolumn{4}{|c|}{ STAN ŁADOWNY WAGONU TOWAROWEGO } \\
\hline $622,56 \mathrm{~N} / \mathrm{mm}$ & $456,73 \mathrm{~N} / \mathrm{mm}$ & $429,56 \mathrm{~N} / \mathrm{mm}$ & $365,82 \mathrm{~N} / \mathrm{mm}$ \\
\hline \multicolumn{4}{|c|}{ STAN PRACY DYNAMICZNEJ WAGONU TOWAROWEGO } \\
\hline $640,71 \mathrm{~N} / \mathrm{mm}$ & $474,43 \mathrm{~N} / \mathrm{mm}$ & $420,78 \mathrm{~N} / \mathrm{mm}$ & $274,51 \mathrm{~N} / \mathrm{mm}$ \\
\hline \multicolumn{4}{|c|}{ STAN PRACY DYNAMICZNEJ WAGONU TOWAROWEGO, ZEROWY LUZ NA ODBIJAKU } \\
\hline $659,06 \mathrm{~N} / \mathrm{mm}$ & $483,52 \mathrm{~N} / \mathrm{mm}$ & $412,43 \mathrm{~N} / \mathrm{mm}$ & $246,60 \mathrm{~N} / \mathrm{mm}$ \\
\hline
\end{tabular}

$$
\mathrm{k}_{\mathrm{YW} 4}=\frac{42730}{\frac{2}{0,011792344}\left(1+\frac{42730}{309389,05}\right) \cdot \operatorname{tg} \frac{0,011792344 \cdot 182}{2}-182}=246,60 \mathrm{~N} / \mathrm{mm}
$$

Wyniki obliczeń charakterystyk poprzecznych przedstawiono w tabeli 2.

Zestawienie sztywności poprzecznych dla układu sprężyn (zewnętrznej oraz wewnętrznej) wózków rodziny Y25L

Tabela 2 
3. Wyznaczenie naprężeń od sil pionowych oraz poprzecznych dla sprężyny zewnętrznej w różnych stanach zaladowania wagonu

Obliczenia naprężeń, wynikających z przemieszczeń pionowych i poprzecznych sprężyny obciazżonej siłą pionową $\mathrm{F}_{\mathrm{Q}}$ oraz siłą $\mathrm{F}_{\mathrm{y}}$ (rys. 2) wyznacza się $\mathrm{z}$ zależności, przedstawionej $\mathrm{w}$ PNEN13298:2003 [10] oraz w normie DIN 2089 część 1 [16]:

$$
\tau=\frac{8}{\pi \cdot d^{3}}\left[F_{Z}\left(D+s_{Q}\right)+F_{Q}(H-d)\right]
$$

$\mathrm{F}_{\mathrm{Z}^{-}}$siła pionowa działająca na sprężynę $(\mathrm{N})$

$\mathrm{s}_{\mathrm{Q}}$ - przemieszczenie poprzeczne sprężyny (dla wózków Y25L wynosi $\pm 10 \mathrm{~mm}$ )

$\mathrm{F}_{\mathrm{Q}}-$ siła poprzeczna $(\mathrm{N})$

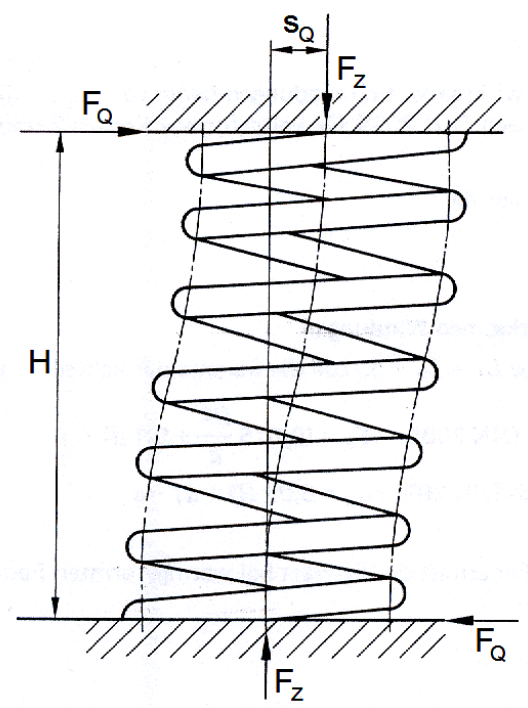

Rys. 2. Obciążenie sprężyny układem sił: pionowej $\mathrm{F}_{Z}$ oraz poprzecznej $\mathrm{F}_{\mathrm{Q}}$
3.1. Wyznaczenie naprężeń od sil pionowych oraz poprzecznych dla sprężyny zewnętrznej $w$ różnych stanach zaladowania wagonu

\subsubsection{Wyznaczenie naprężeń $w$ stanie próżnym wagonu}

Wstawiając do wzoru (73) $\mathrm{d}=31 \mathrm{~mm}, \mathrm{~F}_{\mathrm{Z}}=880 \mathrm{daN}$, $\mathrm{D}=163 \mathrm{~mm}, \mathrm{~s}_{\mathrm{Q}}=10 \mathrm{~mm}, \mathrm{~F}_{\mathrm{Q}}=444,54 \cdot 10 \cdot 10^{-1}=444,54$ daN, $\mathrm{H}_{\mathrm{ZPR}}=242 \mathrm{~mm}$ :

$$
\tau_{1 Z}=\frac{8}{\pi \cdot 31^{3}}[880(163+10)+44,454 \cdot 10 \cdot(242-31)]=21,03 \mathrm{daN} / \mathrm{mm}^{2}
$$

Z uwzględnieniem współczynnika Wahla [1]:

$$
\tau_{\text {IZW }}=21,03 \cdot 1,2761=26,83 \mathrm{daN} / \mathrm{mm}^{2}
$$

\subsubsection{Wyznaczenie naprężeń w stanie ładownym wagonu}

Wstawiając do wzoru (73) $\mathrm{d}=31 \mathrm{~mm}, \mathrm{~F}_{\mathrm{Z}}=2747,5 \mathrm{daN}$, $\mathrm{D}=163 \mathrm{~mm}, \quad \mathrm{~s}_{\mathrm{Q}}=10 \mathrm{~mm}, \quad \mathrm{~F}_{\mathrm{Q}}=456,73 \cdot 10 \cdot 10^{-1}=456,73 \quad$ daN, $\mathrm{H}_{2}=204,83 \mathrm{~mm}$ :

\subsubsection{Wyznaczenie naprężeń $w$ stanie pracy dynamicznej}

Wstawiajac do wzoru (73) d=31 mm, $F_{Z}=3330,16$ daN, $D=163 \mathrm{~mm}, \mathrm{~s}_{\mathrm{Q}}=10 \mathrm{~mm}$, $\mathrm{F}_{\mathrm{Q}}=456,73 \cdot 10 \cdot 10^{-1}=45,673 \mathrm{daN} / \mathrm{mm}, \mathrm{H}_{2}=193,13 \mathrm{~mm}$ :

$$
\tau_{3 Z}=\frac{8}{\pi \cdot 31^{3}}[3330,16 \cdot(163+10)+45,673 \cdot 10 \cdot(193,13-31)]=48,89 \mathrm{daN} / \mathrm{mm}^{2}
$$

Z uwzględnieniem współczynnika Wahla [1]:

$$
\tau_{\text {3ZW }}=48,89 \cdot 1,2671=61,94 \mathrm{daN} / \mathrm{mm}^{2}
$$

3.1.4. Wyznaczenie naprężeń dla sprężyny zewnętrznej w stanie pracy dynamicznej (zerowy luz na odbijaku)

Wstawiajacc do wzoru (73) $\mathrm{d}=31 \mathrm{~mm}, \mathrm{~F}_{\mathrm{Z}}=3868 \mathrm{daN}, \mathrm{D}=163 \mathrm{~mm}, \mathrm{~s}_{\mathrm{Q}}=10 \mathrm{~mm}$, $\mathrm{F}_{\mathrm{Q}}=483,52 \cdot 10 \cdot 10^{-1}=48,352 \mathrm{daN} / \mathrm{mm}, \mathrm{H}_{2}=182,33 \mathrm{~mm}$ :

$$
\tau_{4 Z}=\frac{8}{\pi \cdot 31^{3}}[3868 \cdot(163+10)+45,673 \cdot 10 \cdot(182,33-31)]=57,87 \mathrm{daN} / \mathrm{mm}^{2}
$$

Z uwzględnieniem współczynnika Wahla [1]:

$$
\tau_{4 \mathrm{ZW}}=57,87 \cdot 1,2671=73,32 \mathrm{daN} / \mathrm{mm}^{2}
$$

\subsection{Wyznaczenie naprężeń od sil pionowych oraz poprzecznych dla sprężyny wewnętrznej $w$}

różnych stanach załadowania wagonu

Obliczenia naprężeń, wynikających z przemieszczeń pionowych i poprzecznych sprężyny obciążonej siłą pionową $\mathrm{F}_{\mathrm{Q}}$ oraz siłą $\mathrm{F}_{\mathrm{y}}$ (rys.2) wyznacza się z zależności:

$$
\tau=\frac{8}{\pi \cdot \mathrm{d}_{2}{ }^{3}}\left[\mathrm{~F}_{\mathrm{W}} \cdot\left(\mathrm{D}_{2}+\mathrm{s}_{\mathrm{Q}}\right)+\mathrm{F}_{\mathrm{QW}} \cdot\left(\mathrm{H}-\mathrm{d}_{2}\right)\right]
$$


$\mathrm{F}_{\mathrm{W}^{-}}$siła pionowa działająca na sprężynę $(\mathrm{N})$

$\mathrm{S}_{\mathrm{Q}^{-}}$przemieszczenie poprzeczne sprężyny (dla wózków $\mathrm{Y} 25 \mathrm{~L}$ wynosi $\pm 10 \mathrm{~mm}$ )

$\mathrm{F}_{\mathrm{QW}}$ - siła poprzeczna $(\mathrm{N})$.

3.2.1.Wyznaczenie naprężeń $w$ stanie ladownym wagonu

Wstawiając do wzoru (73) $\mathrm{d}_{2}=24,5 \mathrm{~mm}, \mathrm{~F}_{\mathrm{W} 2}=24220$ daN, $\mathrm{D}_{2}=90 \mathrm{~mm}, \mathrm{~s}_{\mathrm{Q}}=10 \mathrm{~mm}$, $\mathrm{F}_{\mathrm{Q} 2}=365,82 \cdot 10 \cdot 10^{-1}=365,82 \mathrm{daN}, \mathrm{H}_{2 \mathrm{w}}=204,5 \mathrm{~mm}$ :

$$
\tau_{2 \mathrm{~W}}=\frac{8}{\pi \cdot 24,5^{3}}[2424,0 \cdot(90+10)+36,582 \cdot 10 \cdot(204,5-24,5)]=53,37 \mathrm{daN} / \mathrm{mm}^{2}
$$

Z uwzględnieniem współczynnika Wahla [1]:

$$
\tau_{2 \mathrm{Ww}}=53,37 \cdot 1,4251=\mathrm{daN} / \mathrm{mm}^{2}=76,06 \mathrm{daN} / \mathrm{mm}^{2}
$$

\subsubsection{Wyznaczenie naprężeń $w$ stanie pracy dynamicznej}

Wstawiając do wzoru (73) d=24,5 mm, $F_{W_{3}}=3385,389$ daN, $D_{2}=90 \mathrm{~mm}, \mathrm{~s}_{\mathrm{Q}}=10 \mathrm{~mm}$, $\mathrm{F}_{\mathrm{Q}}=274,51 \cdot 10 \cdot 10^{-1}=45,673 \mathrm{daN}, \mathrm{H}_{2}=192,8 \mathrm{~mm}$ :

$$
\tau_{3 \mathrm{~W}}=\frac{8}{\pi \cdot 24,5^{3}}[3330,16 \cdot(90+10)+27,451 \cdot 10 \cdot(192,8-24,5)]=65,66 \mathrm{daN} / \mathrm{mm}^{2}
$$

Z uwzględnieniem współczynnika Wahla [1]:

$$
\tau_{3 \mathrm{Ww}}=65,66 \cdot 1,4251=93,57 \mathrm{daN} / \mathrm{mm}^{2}
$$

\subsubsection{Wyznaczenie naprężeń w stanie pracy do odbijaka}

Wstawiając do wzoru (73) d=24,5 mm, $F_{\mathrm{W} 4}=4273$ daN, $\mathrm{D}_{2}=90 \mathrm{~mm}, \mathrm{~s}_{\mathrm{Q}}=10 \mathrm{~mm}$, $\mathrm{F}_{\mathrm{Q}}=246,60 \cdot 10 \cdot 10^{-1}=246,6 \mathrm{daN}, \mathrm{H}_{3 \mathrm{~W}}=182 \mathrm{~mm}$ :

$$
\tau_{4 \mathrm{~W}}=\frac{8}{\pi \cdot 24,5^{3}}[4273 \cdot(90+10)+24,66 \cdot 10 \cdot(182-24,5)]=80,71 \mathrm{daN} / \mathrm{mm}^{2}
$$

Z uwzględnieniem współczynnika Wahla [1]:

$$
\tau_{4 W W}=80,71 \cdot 1,4251=115 \mathrm{daN} / \mathrm{mm}^{2}
$$

\subsection{Zestawienie wyników obliczeń naprężeń}

\begin{tabular}{|c|c|c|c|}
\hline \multicolumn{2}{|c|}{ Sprężyna zewnętrzna } & \multicolumn{2}{|c|}{ Sprężyna wewnętrzna } \\
\hline $\begin{array}{c}\text { Bez uwzględnienia wspól- } \\
\text { czynnika } \\
\text { Wahla } \\
\end{array}$ & $\begin{array}{c}\mathrm{Z} \text { uwzględnieniem współ- } \\
\text { czynnika } \\
\text { Wahla } \\
\end{array}$ & $\begin{array}{c}\text { Bez uwzględnienia współ- } \\
\text { czynnika } \\
\text { Wahla } \\
\end{array}$ & $\begin{array}{c}\mathrm{Z} \text { uwzględnieniem współ- } \\
\text { czynnika } \\
\text { Wahla } \\
\end{array}$ \\
\hline \multicolumn{4}{|c|}{ STAN PRÓŻNY WAGONU TOWAROWEGO (MASA EKWIWALENTNA 20000 kg) } \\
\hline $21,03 \mathrm{daN} / \mathrm{mm}^{2}$ & $26,83 \mathrm{daN} / \mathrm{mm}^{2}$ & 0 & 0 \\
\hline \multicolumn{4}{|c|}{ STAN ŁADOWNY WAGONU TOWAROWEGO (BRUTTO $900000 \mathrm{~kg}$ ) } \\
\hline $41,30 \mathrm{daN} / \mathrm{mm}^{2}$ & $52,33 \mathrm{daN} / \mathrm{mm}^{2}$ & $53,37 \mathrm{daN} / \mathrm{mm}^{2}$ & $76,06 \mathrm{daN} / \mathrm{mm}^{2}$ \\
\hline \multicolumn{4}{|c|}{ STAN PRACY DYNAMICZNEJ WAGONU TOWAROWEGO } \\
\hline $48,89 \mathrm{daN} / \mathrm{mm}^{2}$ & $61,94 \mathrm{daN} / \mathrm{mm}^{2}$ & $65,66 \mathrm{daN} / \mathrm{mm}^{2}$ & $93,97 \mathrm{daN} / \mathrm{mm}^{2}$ \\
\hline \multicolumn{4}{|c|}{ STAN PRACY DYNAMICZNEJ WAGONU TOWAROWEGO, ZEROWY LUZ NA ODBIJAKU (60 mm $\rightarrow 0 \mathrm{~mm})$} \\
\hline $58,87 \mathrm{daN} / \mathrm{mm}^{2}$ & $73,32 \mathrm{daN} / \mathrm{mm}^{2}$ & $80,71 \mathrm{daN} / \mathrm{mm}^{2}$ & $115 \mathrm{daN} / \mathrm{mm}^{2}$ \\
\hline
\end{tabular}

Zestawienie wyników obliczeń naprężeń od sił pionowych i sił poprzecznych przedstawiono w tabeli 3.

Zestawienie naprężeń od sil pionowych i poprzecznych w sprężynie zewnętrznej i wewnętrznej zawieszenia I-go stopnia wózków rodziny Y25L

Tabela3

Graficzne porównanie naprężeń bez uwzględniania współczynnika Wahla w sprężynach jest przedstawione na diagramie, zamieszczonym na rys.3.

Graficzne porównanie naprężeń z uwzględnieniem współczynnika Wahla w sprężynach jest przedstawione na diagramie, zamieszczonym na rys.4. 


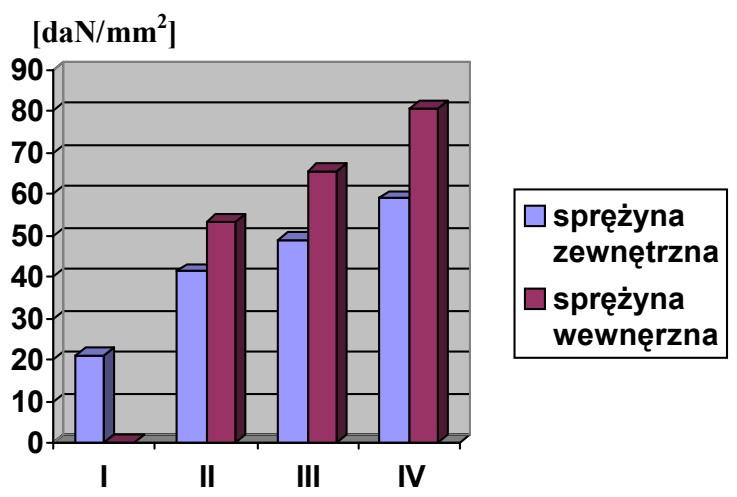

Legenda:

I - stan próżny wagonu

II - stan tadowny wagonu

III - stan pracy dynamicznej (z 30\% nadwyzkka dynamiczna)

$I V$ - stan do wyczerpania luzu na odbijaku

Oś $X$ - różne stany pracy wagonu

Oś $Y$ - naprężenia $w$ daN/mm²

Rys.3. Graficzne porównanie stanu naprężeń, wywołanych obciążeniem pionowym i poprze-cznym w sprężynie zewnętrznej oraz w sprężynie wewnętrznej bez uwzględnienia współczynnika Wahla

Jak widać z przedstawionego porównania, wytężenie materiału sprężyny wewnętrznej jest znacznie większe aniżeli sprężyny zewnętrznej we wszystkich stanach załadowania wagonu towarowego o ekwiwalentnej masie $20000 \mathrm{~kg}$. Dlatego też w eksploatacji dochodzi częściej do pęknięć zmęczeniowych sprężyny wewnętrznej, aniżeli sprężyny zewnętrznej. Pęknięcia najczęściej występują po stronie wewnętrznej, gdzie koncentracja naprężeń z tytułu krzywizny pręta jest większa.

W związku z powyższym na żywotność sprężyn pierwszego stopnia mają wpływ:

- żywotność thumika ciernego, dlatego między innymi na blachy prowadnic ciernych stosuje się trudnościeralną stal kategorii E wg karty UIC 893 [8],

- zastosowanie wysokowytrzymałych materiałów na sprężyny wg normy europejskiej PN-EN 13298:2003 [10],

- nieprzekraczanie dopuszczalnej ładowności wagonu,

- zastosowanie technologii wytwarzania sprężyn zgodnej z kartą UIC 822 [7].

- zastosowanie prętów szlifowanych do produkcji sprężyn,

- zastosowanie sprężyn kategorii 1 wg karty UIC 822 [7], która obejmuje największą ilość badań, zwłaszcza badania magnetoskopowe, mające na celu wykrycie ewentualnych wad powierzchniowych oraz wewnętrznych.

Badania w zależności od kategorii sprężyny przedstawiono w tabeli 4.

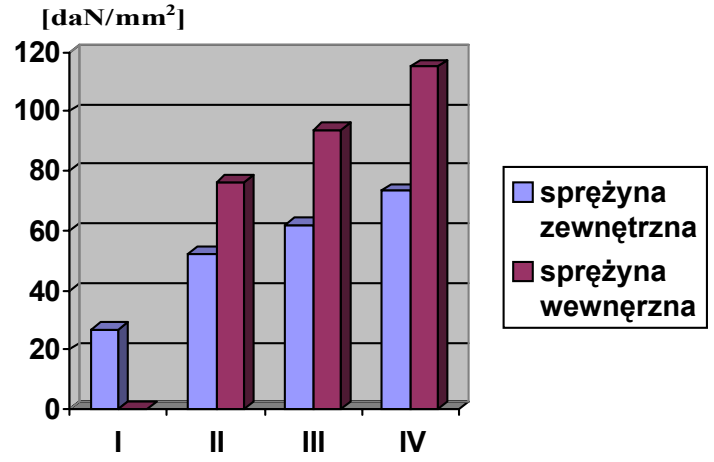

Legenda:

I - stan próżny wagonu

II - stan ładowny wagonu

III - stan pracy dynamicznej wagonu (30\% nadwyżki dynamicznej)

IV - stan do wyczerpania luzu na odbijaku

$O s ́ X$ - różne stany pracy wagonu

Oś $Y$ - naprężenia $w$ daN/mm²

Rys.4. Graficzne porównanie stanu naprężeń w sprężynie zewnętrznej oraz w sprężynie wewnętrznej z uwzględnieniem współczynnika Wahla

Rodzaj i kontrola sprężyn śrubowych naciskowych w zależności od kategorii sprężyny.

Tabela 4

\begin{tabular}{|c|c|c|c|}
\hline \multirow[t]{2}{*}{ Rodzaj kontroli i prób } & \multicolumn{3}{|c|}{$\begin{array}{l}\text { Kategoria } \\
\text { sprężyny }\end{array}$} \\
\hline & 1 & 2 & 3 \\
\hline $\begin{array}{l}\text { Sprawdzenie skuteczności umoc- } \\
\text { nienia powierzchniowego }\end{array}$ & $\mathrm{X}$ & & \\
\hline Twardość ${ }^{1)}$ & $\mathrm{X}$ & $\mathrm{X}$ & \\
\hline Sprężystość krótkotrwała ${ }^{1)}$ & $\mathrm{X}$ & $\mathrm{X}$ & $\mathrm{X}$ \\
\hline Sprężystość długotrwała & $\mathrm{X}$ & $\mathrm{X}$ & \\
\hline Podatnośćc & $\mathrm{X}$ & $\mathrm{X}$ & $\mathrm{X}$ \\
\hline Trwałość & $\mathrm{X}$ & & \\
\hline Odchylenie & $\mathrm{X}$ & & \\
\hline Wady wewnętrzne ${ }^{122) 344)}$ & $\mathrm{X}$ & $\mathrm{X}$ & \\
\hline Wygląd i wymiary & $\mathrm{X}$ & $\mathrm{X}$ & $\mathrm{X}$ \\
\hline
\end{tabular}

1) Każda sprężyna partii przed dostawą i na odpowiedzialność dostawcy powinna być poddana próbie sprężystości krótkotrwałej i jeśli to jest wymagane próbie twardości oraz badaniu wad wewnętrznych za pomocą magnetoskopii

2) Próba ta jest przeprowadzana tylko na podstawie wymagania rysunku w celu dopuszczania nowego typu sprężyny lub nowego rodzaju produkcji. Próba ta obowiązuje w szczególności dla sprężyn zwijanych na zimno

3) Zgodnie $z$ wymaganiami na rysunku drugie badanie magnetoskopem (lub próba penetracji) należy wykonać na wszystkich sprężynach , które były poddane innym próbom przypisanym przez warunki techniczne dostawy, przedstawione w karcie UIC 822[5]

4) Badanie magnetoskopowe może być zastapione przez badanie penetracyjne, zgodnie ze szczególnym wymaganiem zamieszczonym w dokumentacji konstrukcyjnej. 


\section{WNIOSKI}

1. Obliczenia sprężyn przy działaniu sił w kierunku pionowym i poprzecznym wykazały, że sprężyny zawieszenia pierwszego stopnia wózków Y25L należą do elementów bardzo wytężonych. Dotyczy to zarówno obciążeń statycznych jak i zmęczeniowych. Wykazano również, ze sprężyna wewnętrzna jest bardziej obciążona niż sprężyna zewnętrzna. W takiej sytuacji należy zwrócić szczególną uwagę na technologię wykonania, której elementy zostaną przedstawione $\mathrm{w}$ dalszych opracowaniach. Biorąc pod uwagę, że jeśli dokonywałoby się optymalizacji konstrukcji sprężyn, wówczas, należałoby liczyć się z rezygnacją zamienności maźnicy (karta UIC510-1 [4]) oraz thumika ciernego.

2. Wprowadzenie sprężyn $\mathrm{z}$ wózka Y25L do wózków rodziny Y25Cs jest celowe, ale musi pociągać za sobą konieczność wzmocnienia thumika ciernego. Należy jednak zwrócić uwagę, że sprężyny wózków Y25L są sztywniejsze od wózków rodziny Y25Cs i musi być przeprowadzona analiza bezpieczeństwa przejazdu przez tory wichrowate oraz sprawdzenie własności dynamicznych wagonu.

\section{LITERATURA}

[1] Sobaś M: Problematyka usprężynowania wózków wagonów towarowych typu Y25. Pojazdy Szynowe $n r$ $1 / 2014$.

[2] Karta UIC 432:Wagony towarowe. Prędkości jazdy. Warunki techniczne, które należy spetnić. 11-te wydanie 09/2006.

[3] Karta UIC 500: Normalizacja taboru transportowego i jego elementów. Zasady, procedury 2-gie wydanie Grudzień 2000.

[4] Karta UIC 510-1: Wagony towarowe. Uktad biegowy standaryzacja. 9-te wydanie z 1.01.78. 14-ście zmian od 1.01.80 do 1.01.97.

[5] Karta UIC 517: Wagony towarowe. Części zawieszenia resorowego. Normalizacja. 7. wydanie z maja 2007.
[6\} Karta UIC 518: Badania i homologacja pojazdów kolejowych $z$ punktu widzenia wtaściwości dynamicznych, bezpieczeństwa jazdy, obciażenia toru i parametrów biegowych. 4-te wydanie z października 2009.

[7\} Karta UIC 822: Warunki techniczne dostawy sprężyn śrubowych naciskowych formowanych na goraco lub na zimno dla pojazdów trakcyjnych i wagonów. 5-te wydanie z 11.2003

[8] Karta UIC 893: Warunki techniczne dla dostawy blach na ptyty prowadnicowe ze stali manganowej. 2gie wydanie. 06.2004.

[9] PN-EN 10089:2005: Stale walcowane na gorqco na sprężyny ulepszane cieplnie. Warunki techniczne dostawy.

[10] PN-EN 13298:2003: Kolejnictwo. Elementy zawieszenia. Stalowe sprężyny śrubowe zawieszenia.

[11] PN-EN 14363:2007 Kolejnictwo. Badania własności dynamicznych przed dopuszczeniem pojazdów szynowych. Badanie właściwości biegowych i próby stacjonarne.

[12] Raport ORE/ERRI: Frage B12 Vereinheitlichung der Güterwagen. Standard-Drehgestell. Bericht Nr.14.Utrecht, 11.1967.

[13] Schlussbericht ERRI B12/Rp.17 (8-me wydanie): Program badań wagonów towarowych z podwoziem $i$ struktura wagonu ze stali (które nadaja się do zabudowy sprzęgu pracujacego na ściskanie) $i$ których wózki maja ramę stalowq. (Versuchsprogramm für Güterwagen mit Untergestell und Wagenkasten aus Stahl (die für den Einbau der Automatischen Zug-Druck Kupplung geeignet sind) und deren Drehgestelle mit stählernem Drehgestellrahmen). Utrecht, 04.1997.

[14] Raport ORE/ERRI B55: Sicherheit gegen Entgleisen von Güterwagen in Gleisverwindungen. Bericht 8 (Schlussbericht). Utrecht, April 1983.

[15] TSI: Dziennik Urzędowy Unii Europejskiej. Decyzja Komisji z dnia 28 lipca 2006 dotyczaca technicznej specyfikacji dla interoperacyjności odnoszacej się do podsystemu ,tabor kolejowy-wagony towarowe" transeuropejskiego systemu kolei konwencjonalnych.

[16] DIN 2089 Teil 1: Zylindrische Schraubenfedern aus runden Drähten und Stäben. Berechnung und Konstruktion. 